\title{
Simultaneous Hetero- and Isovalent Doping as the Strategy for Improving Transport Properties of Proton Conductors Based on $\mathrm{BaLaInO}_{4}$
}

\author{
Nataliia Tarasova*(D), Anzhelika Galisheva, Irina Animitsa (D) and Ksenia Belova
}

Citation: Tarasova, N.; Galisheva, A.; Animitsa, I.; Belova, K. Simultaneous Hetero- and Isovalent Doping as the Strategy for Improving Transport Properties of Proton Conductors Based on $\mathrm{BaLaInO}_{4}$. Materials 2021, 14, 6240. https://doi.org/10.3390/ ma14216240

Academic Editor: Enrico Negro

Received: 26 September 2021

Accepted: 18 October 2021

Published: 20 October 2021

Publisher's Note: MDPI stays neutral with regard to jurisdictional claims in published maps and institutional affiliations.

Copyright: (c) 2021 by the authors. Licensee MDPI, Basel, Switzerland. This article is an open access article distributed under the terms and conditions of the Creative Commons Attribution (CC BY) license (https:// creativecommons.org/licenses/by/ $4.0 /)$.
The Institute of High Temperature Electrochemistry of the Ural Branch of the Russian Academy of Sciences, 620066 Ekaterinburg, Russia; a.o.galisheva@urfu.ru (A.G.); irina.animitsa@urfu.ru (I.A.); ksenia.belova@urfu.ru (K.B.)

* Correspondence: Natalia.Tarasova@urfu.ru

\begin{abstract}
This work focused on the novel electrochemical energy material with significantly improved electrical properties. The novel complex oxide $\mathrm{Ba}_{1.1} \mathrm{La}_{0.9} \mathrm{In}_{0.5} \mathrm{Y}_{0.5} \mathrm{O}_{3.95}$ with layered perovskite structure was obtained for the first time. It was proven that the simultaneous introduction of barium and yttrium ions in the structure of $\mathrm{BaLaInO}_{4}$ leads to the increase in the unit cell volume of up to $4 \%$ and water uptake by about three times. The increase in the proton conductivity values was both due to an increase in the proton concentration and their mobility. The sample $\mathrm{Ba}_{1.1} \mathrm{La}_{0.9} \mathrm{In}_{0.5} \mathrm{Y}_{0.5} \mathrm{O}_{3.95}$ was a nearly pure proton conductor below $400{ }^{\circ} \mathrm{C}$. The co-doping strategy allowed us to increase the protonic conductivity values up to two orders of magnitude and it is the successful method for the design of novel protonic conductors based on the layered perovskites.
\end{abstract}

Keywords: $\mathrm{BaLaInO}_{4}$; layered perovskite; Ruddlesden-Popper structure; water uptake; oxygen-ion conductivity; protonic conductivity

\section{Introduction}

The proton-conducting solid oxides were revealed for the first time at the early 1980s. The first of these were derivative from $\mathrm{SrCeO}_{3}$ and characterized by the perovskite structure [1-3]. The progress of materials science research of proton-conducting systems was due to the possibility of using them in the different energy-related applications like solid oxide fuel cell. Today, the problem of creation of high-efficiency, long-term, and low-cost devices is especially relevant due to the need to switchover to clean and renewable energy sources [4-7]. Over the past forty years, the proton-conducting solid oxides went beyond perovskites family (Figure 1). After variously doped barium cerates and zirconates [8-10], classes of proton-conducting materials like hexagonal [11-17], oxygen-deficient [18-20], block-layered [21-31] perovskites, brownmillerites [32-34], pyrochlores [35-38], apatites [39], monazites [40-42], gallium-based oxides [43-45], materials with fluorite- [46-48], fergusonite- [49-51], and weberite-types [52,53] of structures were described.

In general, the realization of proton transfer is provided by the dissociative water uptake from the gas phase into the crystal lattice of the solid oxide. However, the crystal structure features determine the sites of protons localization. For oxides like doped barium cerates and zirconates, the proton species localize in the oxygen vacancies that appear through the acceptor doping [54]:

$$
\mathrm{V}_{\mathrm{o}}^{\bullet \bullet}+\mathrm{H}_{2} \mathrm{O}+\mathrm{O}_{\mathrm{o}}^{\times} \leftrightarrow 2(\mathrm{OH})_{\mathrm{o}}^{\bullet}
$$




\section{PROTON-CONDUCTING SOLID OXIDES}

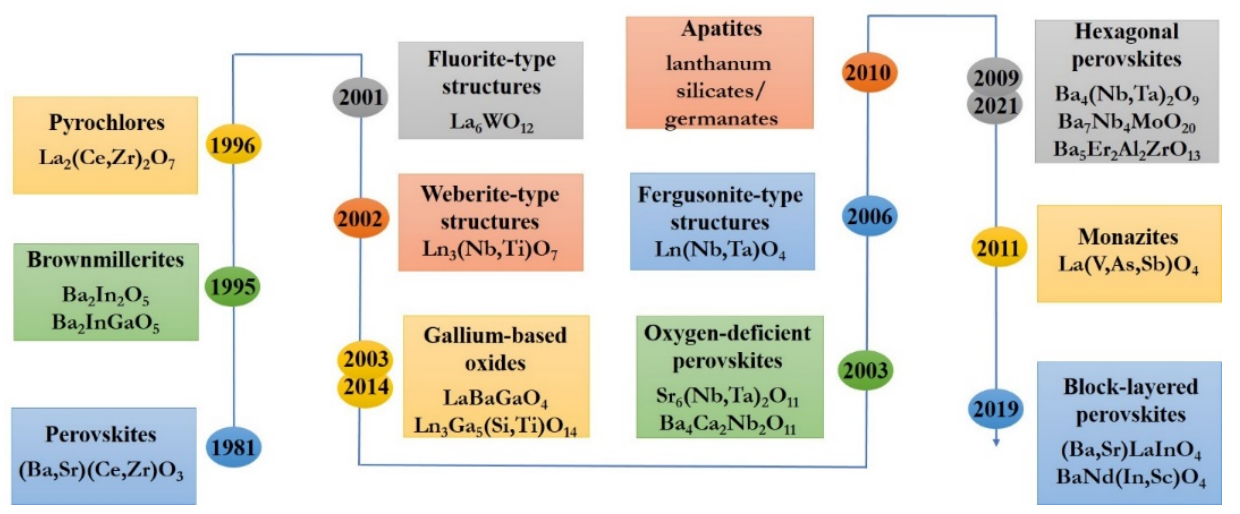

Figure 1. Historical overview on the development of proton-conducting solid oxides.

In such systems, the amount of protons is small and limited by the amount of dopant. The oxygen-deficient perovskites and brownmillerites have oxygen vacancies in the structure without doping up to $0.5 \mathrm{~mol}$ per perovskite $\mathrm{ABO}_{3}$ formula unit. This leads to a significant increase in the amount of water uptake compared with doped perovskites [54]:

$$
\mathrm{V}_{\mathrm{o}}^{\times}+\mathrm{H}_{2} \mathrm{O}+2 \mathrm{O}_{\mathrm{o}}^{\times} \leftrightarrow 2(\mathrm{OH})_{\mathrm{o}}^{\bullet}+\mathrm{O}_{i}^{\prime \prime}
$$

In the structure of layered perovskites $\mathrm{AA}^{\prime} \mathrm{BO}_{4}$ the alternation of salt layers [AO] and perovskite layers $\left[\mathrm{A}^{\prime} \mathrm{BO}_{3}\right]$ provides the presence of interlayer space in the structure, which is suitable for the insertion of protonic species up to 3 mol theoretically:

$$
\mathrm{H}_{2} \mathrm{O}+\mathrm{O}_{\mathrm{o}}^{\times} \leftrightarrow(\mathrm{OH})_{\mathrm{o}}^{\bullet}+(\mathrm{OH})_{\mathrm{i}}^{\prime}
$$

From the point of view of protonic conductivity, the layered perovskites based on $\mathrm{BaLaInO}_{4}, \mathrm{SrLaInO}_{4}, \mathrm{BaNdInO}_{4}$, and $\mathrm{BaNdScO}_{4}$ were investigated [21-31]. The possibility of acceptor $\left(\mathrm{Ca}^{2+} / \mathrm{Sr}^{2+} / \mathrm{Ba}^{2+} \rightarrow \mathrm{La}^{3+} / \mathrm{Nd}^{3+}\right)$ and donor $\left(\mathrm{Zr}^{4+} / \mathrm{Ti}^{4+} / \mathrm{Nb}^{5+} \rightarrow \mathrm{In}^{3+}\right)$ doping was proven. It was shown that a significant amount of protons (up to $1.5 \mathrm{~mol}$ ) are achieved only for doped compositions, and the increase of dopant concentration leads to the increase in water uptake due to increase in the interlayer space [31]. In the other words, the amount of proton current carriers in the structure increases with an increasing acceptor or dopant content. However, it is well known that the value of protonic conductivity is determined not only by the amount of protonic species but by their mobility as well. The mobility of protons depends on the many factors, including the bond energy with nearest atoms, the possibility to use the migration pathways and the presence of other structural defects. The last factor plays a significant role not only for the classic doped perovskites, but also for the novel block-layer proton conductors. It was shown that the formation of proton-aggregating clusters can be obtained at a small enough amount of acceptor or donor dopant [26,27]:

$$
\begin{aligned}
& \mathrm{M}_{\mathrm{A}}^{\prime}+(\mathrm{OH})_{\mathrm{o}}^{\bullet} \rightarrow\left(\mathrm{M}_{\mathrm{A}}^{\prime} \cdot(\mathrm{OH})_{\mathrm{o}}^{\bullet}\right)^{\times} \\
& \mathrm{M}_{\mathrm{B}}^{\bullet}+(\mathrm{OH})_{\mathrm{i}}^{\prime} \rightarrow\left(\mathrm{M}_{\mathrm{B}}^{\bullet} \cdot(\mathrm{OH})_{\mathrm{i}}^{\prime}\right)^{\times}
\end{aligned}
$$

This means that increase in the acceptor/donor dopant concentration leads to the trapping of protons. Therefore, this way (increase in dopant concentration of $\mathrm{M}_{\mathrm{A}}^{\prime}$ or $\mathrm{M}_{\mathrm{B}}{ }_{\mathrm{B}}$ ) is not prospective for obtaining of block-layered materials with high values of proton conductivity. On the other hand, for layered perovskites, it is known that an increase in the water uptake occurs with an increase in the size of the salt block, and this can be achieved by isovalet doping with a larger ion. Therefore, the strategy of introducing two types of dopants can lead to a more significant increase in proton conductivity. 
In this paper, a novel method of improving of proton conductors based on blocklayered perovskite $\mathrm{BaLaInO}_{4}$ is proposed. The idea of creation of an "optimal" concentration of oxygen vacancies by introducing the acceptor dopant $\mathrm{Ba}^{2+} \rightarrow \mathrm{La}^{3+}$ while simultaneously increasing the interlayer space by the isovalent doping $\mathrm{Y}^{3+} \rightarrow \mathrm{In}^{3+}$ by ions with bigger ionic radii is realized. The composition of $\mathrm{Ba}_{1.1} \mathrm{La}_{0.9} \mathrm{In}_{0.5} \mathrm{Y}_{0.5} \mathrm{O}_{3.95}$ was obtained for the first time. The possibility for water uptake and realization of fast protonic transport was revealed.

It can be said that the block-layered perovskites are one of the newest classes among proton-conducting solid oxides and require further investigation.

\section{Materials and Methods}

The composition of $\mathrm{Ba}_{1.1} \mathrm{La}_{0.9} \mathrm{In}_{0.5} \mathrm{Y}_{0.5} \mathrm{O}_{3.95}$ was prepared by a solid-state method. The initial powders of $\mathrm{BaCO}_{3}, \mathrm{La}_{2} \mathrm{O}_{3}, \mathrm{In}_{2} \mathrm{O}_{3}, \mathrm{Y}_{2} \mathrm{O}_{3}$ were dried and weighed using Sartorius balances. The reagents were milling in an agate mortar and then calcined at $800-1300{ }^{\circ} \mathrm{C}$ (step of $100{ }^{\circ} \mathrm{C}$, time of calcined $24 \mathrm{~h}$ ). Figure 2 provides the pictures of the powders of the initial materials and the obtained composition. Figure 3 represents the scheme indicating the workflow and analysis.

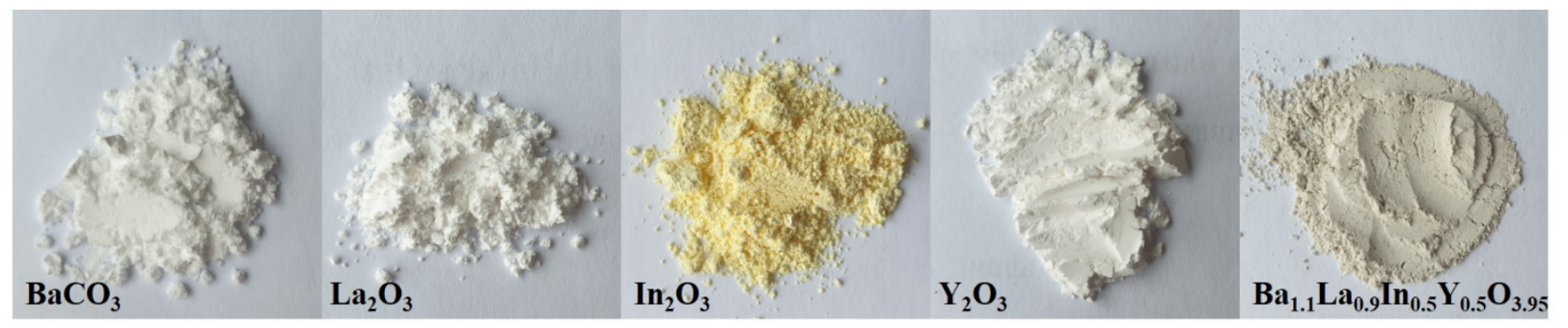

Figure 2. The pictures of powders of initial materials and obtained composition.

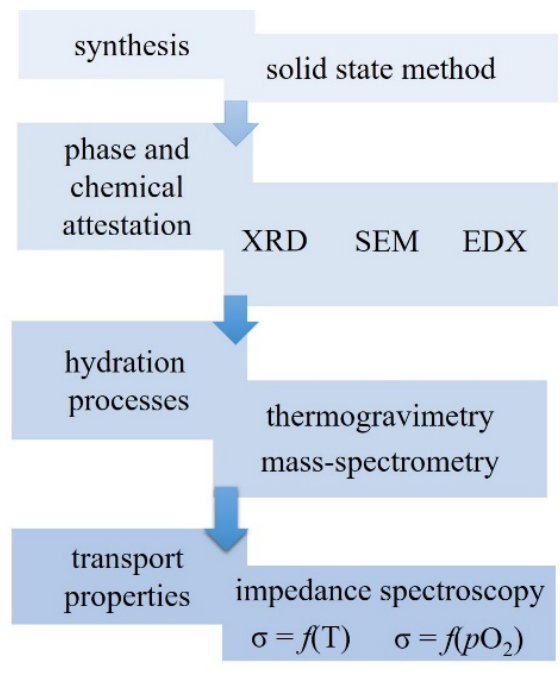

Figure 3. The scheme indicating the workflow and analysis.

The monitoring of the phase purity of the samples was performed using a Bruker Advance D8 $\mathrm{Cu} \mathrm{K}{ }_{\alpha}$ diffractometer with $\mathrm{Cu} \mathrm{K} \alpha$ radiation in the range of $2 \theta=10-80^{\circ}$ with a step of $0.01^{\circ}$ and at a scanning rate of $0.5^{\circ} / \mathrm{min}$. The scanning electron microscope JEOL JSM-6390 LV (WD $8.1 \mathrm{~mm}$, aperture size $30 \mu \mathrm{m}$, EHT $20 \mathrm{kV}$, system vacuum $1.68 \times 10^{-6} \mathrm{mbar}$ ) was used to determine the morphology and chemical composition of the samples.

Thermogravimetry (TG) and mass-spectrometry (MS) analysis were performed using the STA 409 PC Netzsch Analyser coupled with a QMS 403 C Aëolos mass spectrometer. 
The preliminarily hydrated samples were heated at the rate of $10^{\circ} \mathrm{C} / \mathrm{min}$ in a corundum crucible under a flow of dry Ar at the temperature range of $40-1100{ }^{\circ} \mathrm{C}$. The hydrated forms of the samples were prepared by slow cooling $\left(1^{\circ} \mathrm{C} / \mathrm{min}, 1100-150^{\circ} \mathrm{C}\right)$ in wet Ar.

The impedance spectroscopy measurements were performed on the pressed cylindrical pellets $\left(1300{ }^{\circ} \mathrm{C}, 24 \mathrm{~h}\right)$ using a Z-1000P (Elins, RF) impedance spectrometer. The measurements were carried out in the temperature range $200-1000{ }^{\circ} \mathrm{C}$ every $10-20{ }^{\circ} \mathrm{C}$ with a cooling rate of $1^{\circ} / \mathrm{min}$ under dry and wet air or Ar. Dry gas was obtained by the circulation through $\mathrm{P}_{2} \mathrm{O}_{5}\left(p \mathrm{H}_{2} \mathrm{O}=3.5 \times 10^{-5} \mathrm{~atm}\right)$. Wet gas was produced by bubbling first through distilled water and then through saturated solution of $\mathrm{KBr}\left(p \mathrm{H}_{2} \mathrm{O}=2 \times 10^{-2} \mathrm{~atm}\right)$. The conductivity was also measured at different partial oxygen pressures $p \mathrm{O}_{2}$ for some temperatures. The $\mathrm{pO}_{2}$ was controlled by electrochemical method. The oxygen pump (and sensor) from Y-stabilized $\mathrm{ZrO}_{2}$ ceramic was used to control (and measure) $p \mathrm{O}_{2}$. Before the measurements, the samples were equilibrated up to constant values of resistance for 3-5 h.

\section{Results and Discussion}

\subsection{X-ray, SEM and TG Characterization}

The phase composition of the obtained sample $\mathrm{Ba}_{1.1} \mathrm{La}_{0.9} \mathrm{In}_{0.5} \mathrm{Y}_{0.5} \mathrm{O}_{3.95}$ was checked via scanning electron microscopy (SEM) coupled with energy dispersive analysis (EDS). Figure 4 shows the morphology of the powder sample. The grains of co-doped sample are round-shaped $(\sim 3-5 \mu \mathrm{m})$ and form the agglomerates of 10-20 $\mu \mathrm{m}$ with an irregular shape. An element analysis was performed at the polished cleavages of the ceramic samples via the EDS method. The experimental content of the elements was in good agreement with the theoretical values (Table 1).

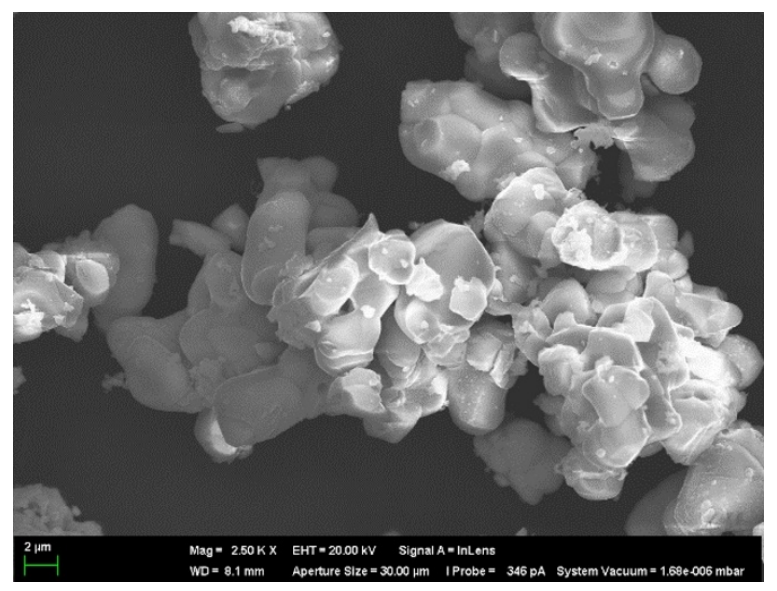

(a)

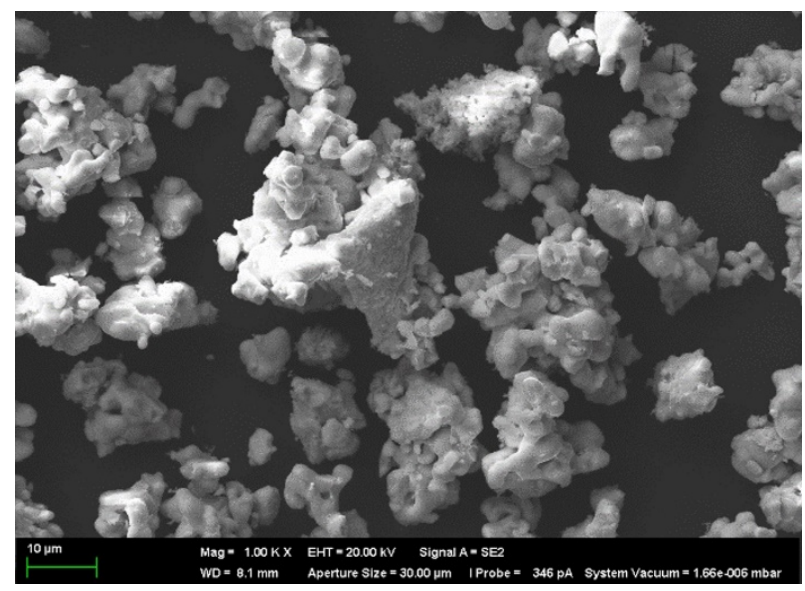

(b)

Figure 4. The SEM-images of the composition $\mathrm{Ba}_{1.1} \mathrm{La}_{0.9} \mathrm{Y}_{0.5} \mathrm{In}_{0.5} \mathrm{O}_{3.95}(\mathbf{a}, \mathbf{b})$

Table 1. The average element ratios determined by EDS analysis for the sample $\mathrm{Ba}_{1.1} \mathrm{La}_{0.9} \mathrm{In}_{0.5} \mathrm{Y}_{0.5} \mathrm{O}_{3.95}$.

\begin{tabular}{ccc}
\hline \multirow{2}{*}{ Element } & \multicolumn{2}{c}{ Content of the Elements, Atomic \% } \\
\cline { 2 - 3 } & Theoretical & Experimental \\
\hline Ba & 15.8 & 15.1 \\
La & 12.9 & 11.4 \\
In & 7.2 & 6.9 \\
Y & 7.2 & 6.8 \\
O & 56.9 & 59.8 \\
\hline
\end{tabular}

The XRD pattern of the co-doped sample $\mathrm{Ba}_{1.1} \mathrm{La}_{0.9} \mathrm{In}_{0.5} \mathrm{Y}_{0.5} \mathrm{O}_{3.95}$ is shown in Figure 5 . (Figure 5a). It is observed that all reflexes belong to the phase with orthorhombic symmetry, so the sample exhibits an RP-structure with the Pbca space group in agreement with the XRD 
data for the parent phase $\mathrm{BaLaInO}_{4}$ [24]. The cell parameters for undoped $\mathrm{BaLaInO}_{4}$ [24] and doped $\mathrm{Ba}_{1.1} \mathrm{La}_{0.9} \mathrm{InO}_{3.95}$ [24], $\mathrm{Ba}_{1.1} \mathrm{La}_{0.9} \mathrm{In}_{0.5} \mathrm{Y}_{0.5} \mathrm{O}_{3.95}$ samples are shown in Table 2 . As it was shown earlier, the acceptor doping of lanthanum sublattice $\mathrm{Ba}^{2+} \rightarrow \mathrm{La}^{3+}$ led to an increase in all unit cell parameters and the unit cell volume. The simultaneous doping $\mathrm{Ba}^{2+} \rightarrow \mathrm{La}^{3+}$ and $\mathrm{Y}^{3+} \rightarrow \mathrm{In}^{3+}$ leads to the same effect, but the increase in the unit cell volume during co-doping is bigger $(\sim 4 \%)$ compared with increase in the case of only acceptor doping $(\sim 1 \%)$. It should be noted that the compositions with a yttrium content over $50 \%$ were not singe phases (Figure $5 b$, line 4 ). After measuring the conductivity of the synthesized phase $\mathrm{Ba}_{1.1} \mathrm{La}_{0.9} \mathrm{In}_{0.5} \mathrm{Y}_{0.5} \mathrm{O}_{3.95}$ as a function of $\mathrm{pO}_{2}$ at different temperatures and high humidity, X-ray powder diffraction patterns of the pellets were obtained (Figure $5 b$. line 3). Decomposition, due to the highly reduced atmosphere or to the high humidity to which the materials were exposed, did not take place.
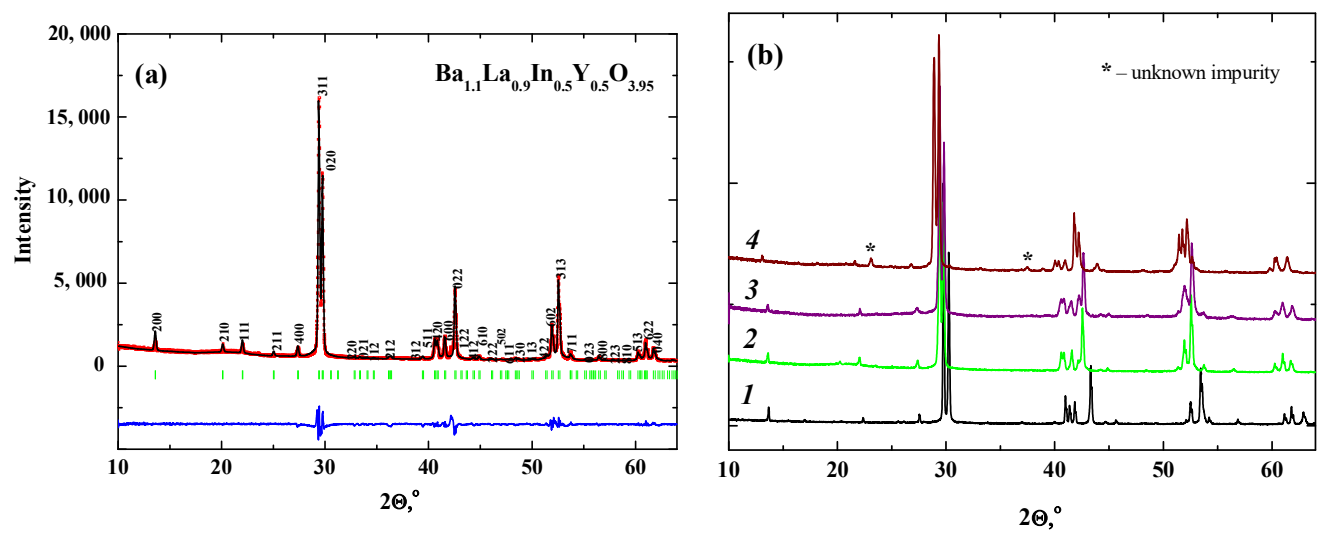

Figure 5. The refinement of XRD-data for the composition $\mathrm{Ba}_{1.1} \mathrm{La}_{0.9} \mathrm{Y}_{0.5} \operatorname{In}_{0.5} \mathrm{O}_{3.95}$ (a) and the XRDdata for $\mathrm{BaLaInO}_{4}$ (1), $\mathrm{Ba}_{1.1} \mathrm{La}_{0.9} \mathrm{Y}_{0.5} \mathrm{In}_{0.5} \mathrm{O}_{3.95}$ before (2) and after (3) electrochemical measurements and for $\mathrm{Ba}_{1.1} \mathrm{La}_{0.9} \mathrm{Y}_{0.6} \mathrm{In}_{0.4} \mathrm{O}_{3.95}$ (4) (b).

Table 2. The lattice parameters, unit cell volume and amount of water uptake for the samples $\mathrm{BaLaInO}_{4}$ [24], $\mathrm{Ba}_{1.1} \mathrm{La}_{0.9} \mathrm{InO}_{3.95}$ [24], $\mathrm{Ba}_{1.1} \mathrm{La}_{0.9} \mathrm{Y}_{0.5} \mathrm{In}_{0.5} \mathrm{O}_{3.95}$.

\begin{tabular}{|c|c|c|c|c|c|c|}
\hline Sample & $\mathrm{a}, \AA$ & $\mathbf{b}, \AA$ & c, $\AA$ & $\begin{array}{l}\text { Cell Volume, } \\
\left(\AA^{3}\right)\end{array}$ & $\begin{array}{l}\text { Increase of Cell } \\
\text { Volume, \% }\end{array}$ & Water Uptake \\
\hline $\mathrm{BaLaInO}_{4}$ & $12.932(3)$ & $5.906(0)$ & $5.894(2)$ & $450.18(8)$ & - & 0.62 \\
\hline $\mathrm{Ba}_{1.1} \mathrm{La}_{0.9} \mathrm{InO}_{3.95}$ & $13.002(1)$ & $5.919(3)$ & $5.901(3)$ & $454.18(8)$ & 0.89 & 1.05 \\
\hline $\mathrm{Ba}_{1.1} \mathrm{La}_{0.9} \mathrm{Y}_{0.5} \mathrm{In}_{0.5} \mathrm{O}_{3.95}$ & $13.059(6)$ & $5.997(5)$ & $5.993(5)$ & $469.44(0)$ & 4.28 & 1.90 \\
\hline
\end{tabular}

The possibility for the dissociative water incorporation from the gas phase was checked using the thermogravimetry (TG) method. The mass loss of preliminary hydrated sample $\mathrm{Ba}_{1.1} \mathrm{La}_{0.9} \mathrm{In}_{0.5} \mathrm{Y}_{0.5} \mathrm{O}_{4.95} \cdot n \mathrm{H}_{2} \mathrm{O}$ was $93.5 \%$ (Figure 6). The mass spectrometry (MS) analysis showed that all mass loss was a result of only water removal. The calculated amount of mole of water per the formula unit is presented in the Table 2. As we can see, the water uptake increases with the increasing unit cell volume. As shown earlier [31], the amount of water uptake for layered perovskites based on $\mathrm{BaLaInO}_{4}$ is determined not by the amount of oxygen vacancies but by the size of unit cell volume. The result obtained for the co-doped sample $\mathrm{Ba}_{1.1} \mathrm{La}_{0.9} \operatorname{In}_{0.5} \mathrm{Y}_{0.5} \mathrm{O}_{3.95}$ is in agreement with this statement. 


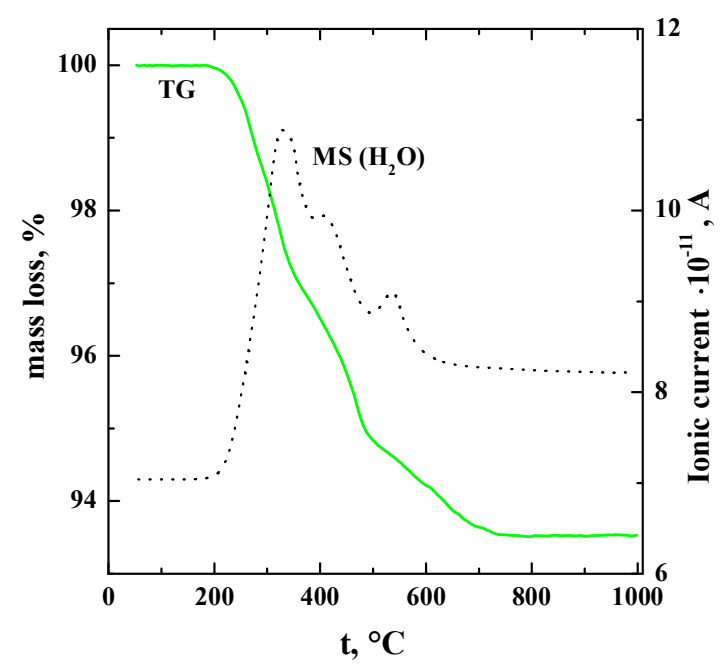

Figure 6. The TG- and MS-data for the composition $\mathrm{Ba}_{1.1} \mathrm{La}_{0.9} \mathrm{Y}_{0.5} \mathrm{In}_{0.5} \mathrm{O}_{3.95}$.

\subsection{Electrical Properties}

The electrical properties of the obtained sample were investigated via the impedance spectroscopy method. The comparison of Nyquist plots for undoped $\mathrm{BaLaInO}_{4}$ and doped $\mathrm{Ba}_{1.1} \mathrm{La}_{0.9} \mathrm{In}_{0.5} \mathrm{Y}_{0.5} \mathrm{O}_{3.95}$ samples is presented in Figure $7 \mathrm{a}\left(500{ }^{\circ} \mathrm{C}\right.$, dry air). As can be seen, the doping does not affect to the general view of the plots. The one semicircle starting from zero coordinates and corresponding to the bulk component $\left(C_{\text {bulk }} \sim 10^{-11} \mathrm{~F} \cdot \mathrm{cm}^{-1}\right)$ of conductivity is observed for both samples. The bulk conductivity value for the doped sample $\mathrm{Ba}_{1.1} \mathrm{La}_{0.9} \mathrm{In}_{0.5} \mathrm{Y}_{0.5} \mathrm{O}_{3.95}$ is about $4 \mathrm{k} \Omega$ at $500{ }^{\circ} \mathrm{C}$ in the dry air (green symbols in Figure 7a) which is higher by almost two orders of magnitude than for the undoped sample ( $300 \mathrm{k} \Omega$, black symbols in Figure 7a). As an example of the evolution of spectra, the Nyquist plots obtained in the wet air for the composition $\mathrm{Ba}_{1.1} \mathrm{La}_{0.9} \mathrm{In}_{0.5} \mathrm{Y}_{0.5} \mathrm{O}_{3.95}$ are presented in Figure $7 \mathrm{~b}$.
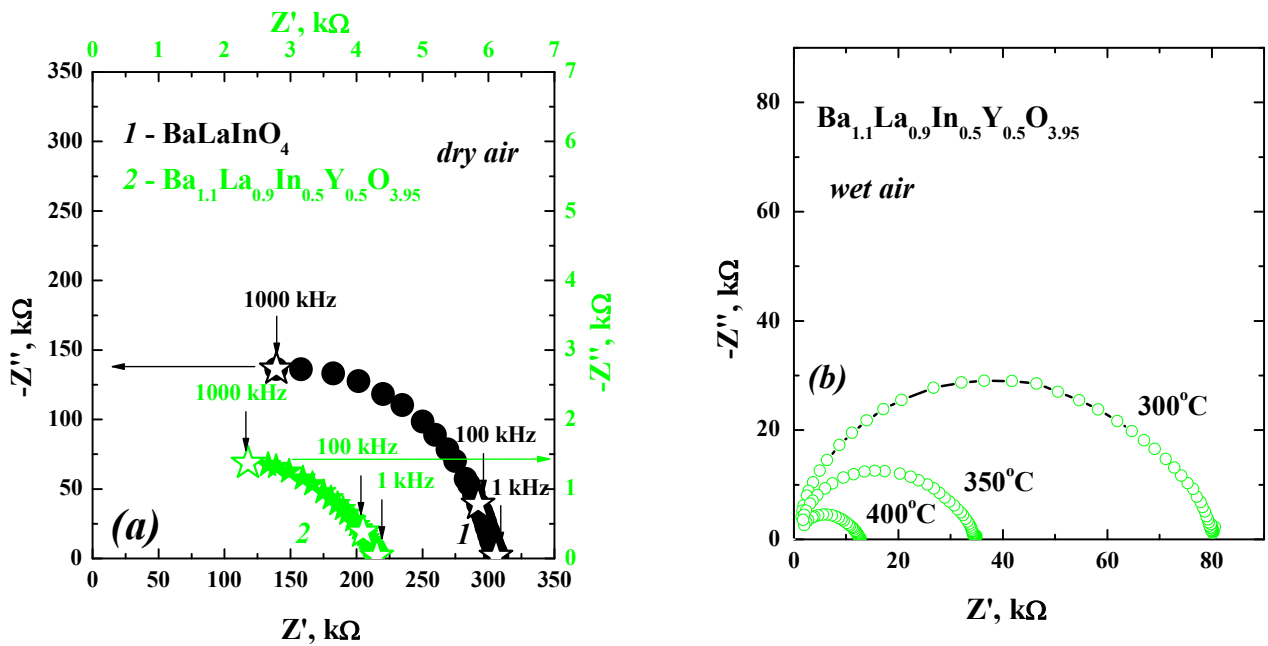

Figure 7. The Nyquist plots for the compositions $\mathrm{BaLaInO}_{4}$ [24] (1) and $\mathrm{Ba}_{1.1} \mathrm{La}_{0.9} \mathrm{Y}_{0.5} \mathrm{In}_{0.5} \mathrm{O}_{3.95}$ (2) obtained at $500{ }^{\circ} \mathrm{C}$ under dry air (a) and for the composition $\mathrm{Ba}_{1.1} \mathrm{La}_{0.9} \mathrm{Y}_{0.5} \mathrm{In}_{0.5} \mathrm{O}_{3.95}$ obtained at different temperatures under wet air (b).

The nature of charge carriers was discovered by investigating conductivity through the variation of oxygen partial pressure. The dependencies of conductivity vs. $p \mathrm{O}_{2}$ at different temperatures for the doped sample $\mathrm{Ba}_{1.1} \mathrm{La}_{0.9} \mathrm{In}_{0.5} \mathrm{Y}_{0.5} \mathrm{O}_{3.95}$ are presented in Figure 8. The 
positive slope of the conductivity curves obtained in the dry oxidizing conditions $\left(p \mathrm{O}_{2}=\right.$ $10^{-5}-0.21 \mathrm{~atm}$ ) indicates the mixed ionic-electronic (hole) nature of conductivity:

$$
1 / 2 \mathrm{O}_{2} \leftrightarrow \mathrm{O}_{\mathrm{i}}^{\prime \prime}+2 h^{\bullet}
$$

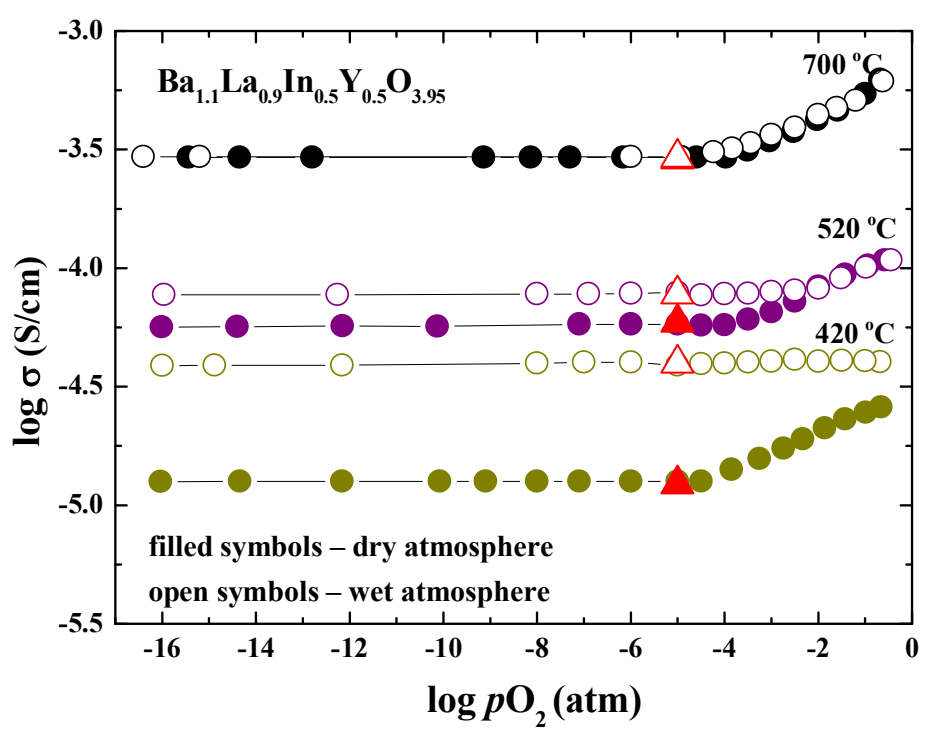

Figure 8. The total conductivity vs. $p \mathrm{O}_{2}$ for the composition $\mathrm{Ba}_{1.1} \mathrm{La}_{0.9} \mathrm{Y}_{0.5} \operatorname{In}_{0.5} \mathrm{O}_{3.95}$ at dry (filled symbols) and wet (open symbols) conditions; and conductivity values from $\sigma-10^{3} / T$ dependencies at dry Ar (red symbols).

The electrolytic area $\left(p \mathrm{O}_{2}=10^{-16}-10^{-5} \mathrm{~atm}\right)$ is characterized by an independence of conductivity values from oxygen partial pressure which indicates the domination of oxygen-ionic conductivity in this $p \mathrm{O}_{2}$ region. The effect of humidity in the atmosphere is shown to start below $700{ }^{\circ} \mathrm{C}$. The conductivity values increase in the electrolytic area up to half an order of magnitude at $420^{\circ} \mathrm{C}$, which indicates the appearance of proton current carriers (Equation (3)). In the area of wet oxidizing conditions, the interaction of holes with water leads to the formation of protons:

$$
h^{\bullet}+1 / 2 \mathrm{H}_{2} \mathrm{O}+\mathrm{O}_{i}^{\prime \prime} \leftrightarrow 1 / 4 \mathrm{O}_{2}+(\mathrm{OH})_{i}^{\prime}
$$

The effect of humidity of atmosphere on the transport properties was investigated at the different temperatures. The example of initial data is presented in the Figure 9a. During the measurement, the sample was held at each temperature until the resistances became constant. It can be seen that the switching from dry to wet atmosphere leads to a decrease in the resistance values, i.e., to an increase in the values of electrical conductivity. The temperature dependencies of conductivity for the doped sample $\mathrm{Ba}_{1.1} \mathrm{La}_{0.9} \mathrm{In}_{0.5} \mathrm{Y}_{0.5} \mathrm{O}_{3.95}$ obtained for the different conditions are presented in Figure 9b. The conductivity values in the dry air (filled black symbol) were higher than that in the dry Ar (filled green symbol) by about 0.3 order of magnitude. This indicates the mixed ionic-electronic nature of conductivity in the whole temperature range. An increase in the humidity of the atmosphere led to an increase in the conductivity values compared with dry conditions. The conductivity values in the wet air (open black symbol) and wet Ar (open green symbol) were the same at temperatures lower than $400{ }^{\circ} \mathrm{C}$, indicating the domination of proton transport in this area. It should be noted that the conductivity values obtained in the $\mathrm{Ar}$ $\left(p \mathrm{O}_{2} \sim 10^{-5} \mathrm{~atm}\right)$ were matched with the values from the electrolytic area (red symbols in Figure 8). Thus, the values obtained in the dry Ar can be considered as oxygen-ionic conductivity values. 

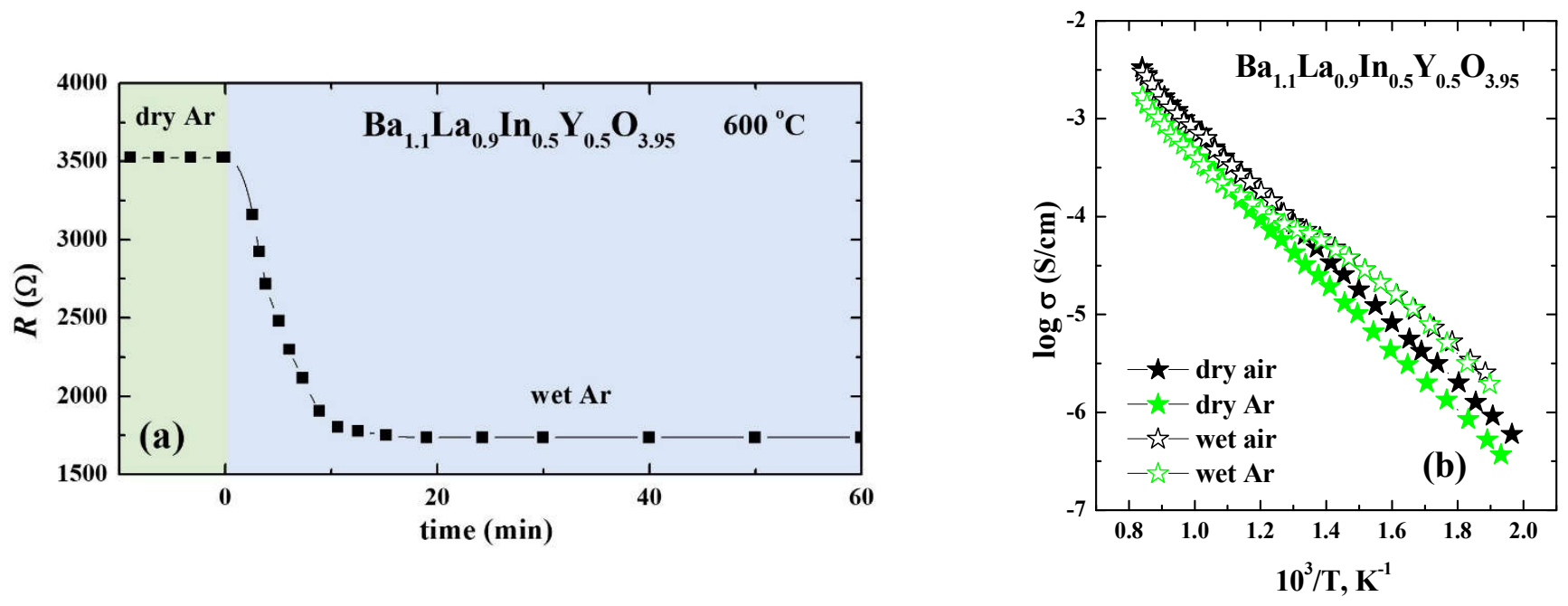

Figure 9. The resistance as a function of exposure time for the sample $\mathrm{Ba}_{1.1} \mathrm{La}_{0.9} \mathrm{Y}_{0.5} \mathrm{In}_{0.5} \mathrm{O}_{3.95}$ obtained during switched from dry Ar to wet Ar atmosphere (a), and the temperature dependencies of conductivities for the composition $\mathrm{Ba}_{1.1} \mathrm{La}_{0.9} \mathrm{Y}_{0.5} \mathrm{In}_{0.5} \mathrm{O}_{3.95}$ obtained under dry (open symbols) and wet (filled symbols) air (black symbols) and Ar (green symbols) (b).

Figure 10 represents the comparison of temperature dependencies of conductivity obtained for the different conditions (dry/wet air and $\mathrm{Ar}$ ). As can be seen, the conductivity increases in the row $\mathrm{BaLaInO}_{4}-\mathrm{Ba}_{1.1} \mathrm{La}_{0.9} \mathrm{InO}_{3.95}-\mathrm{Ba}_{1.1} \mathrm{La}_{0.9} \mathrm{In}_{0.5} \mathrm{Y}_{0.5} \mathrm{O}_{3.95}$ for all conditions, i.e., in the row of an increasing unit cell volume and interlayer space (space between perovskite octahedra layers). It was shown that ionic transport for layered perovskites like $\mathrm{BaNdInO}_{4}$ [22] and $\mathrm{BaLaScO}_{4}$ [23] occurs via oxygen jumps between apical oxygens in the perovskite octahedra and oxygens in the salt layers, i.e., in the interlayer space of the layered structure. We can suggest that the same mechanism of oxygen transport is realized for the layered perovskites based on $\mathrm{BaLaInO}_{4}$.
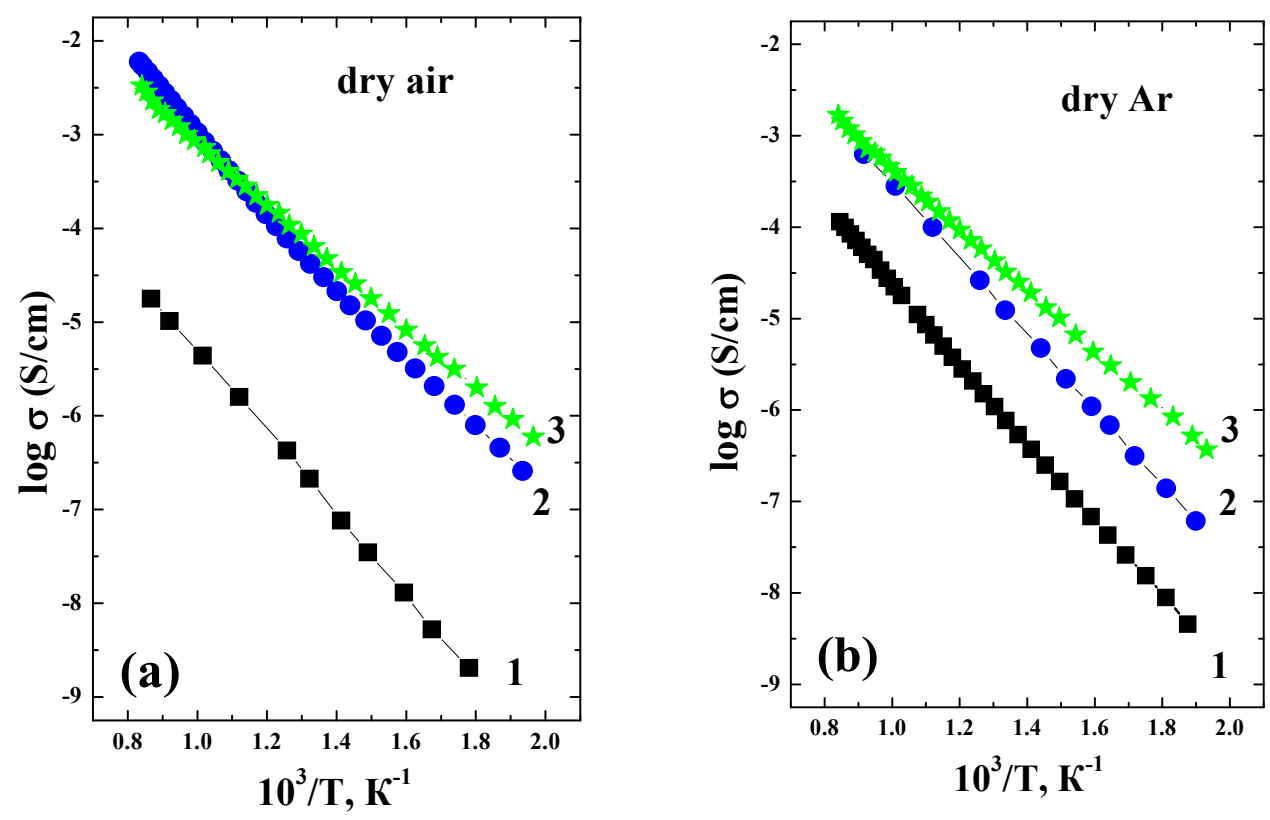

Figure 10. Cont. 

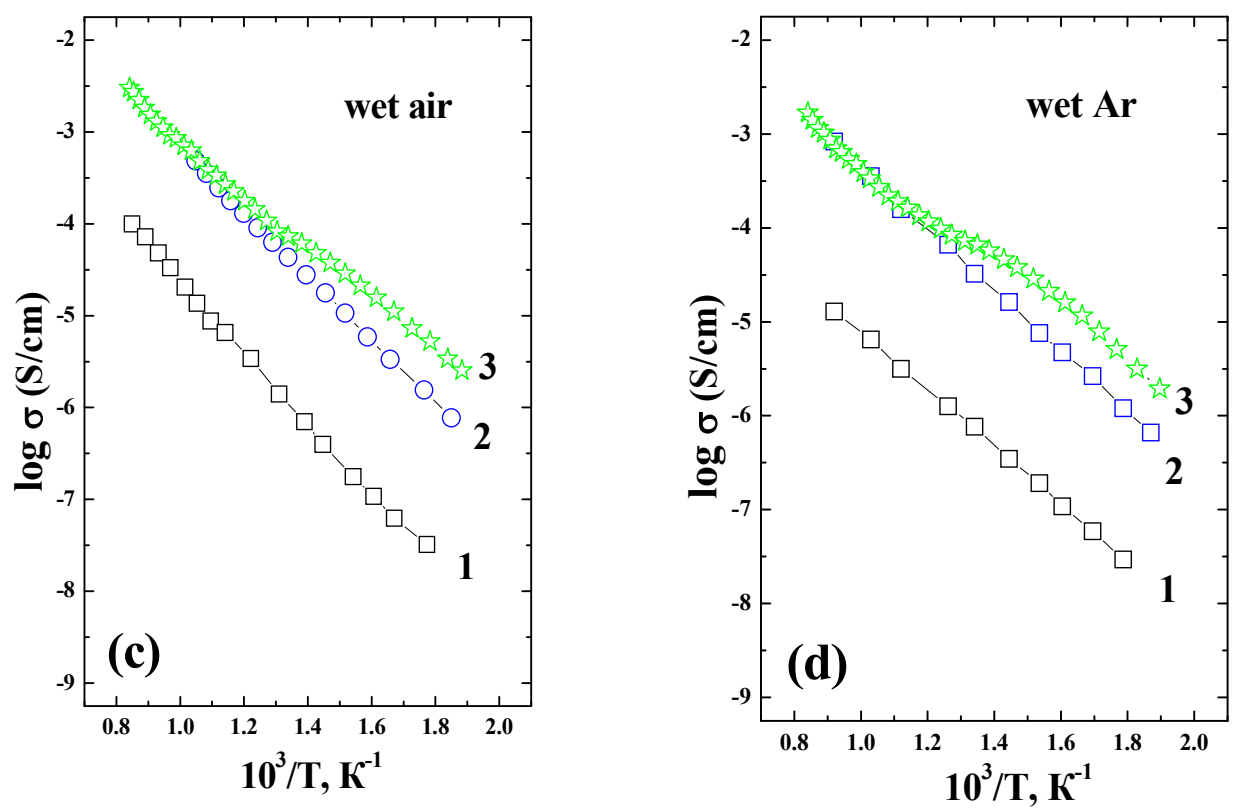

Figure 10. The temperature dependencies of conductivities for the $\mathrm{BaLaInO}_{4}$ [24] (1), $\mathrm{Ba}_{1.1} \mathrm{La}_{0.9} \mathrm{InO}_{3.95}$ [24] (2), and $\mathrm{Ba}_{1.1} \mathrm{La}_{0.9} \mathrm{In}_{0.5} \mathrm{Y}_{0.5} \mathrm{O}_{3.95}$ (3) obtained under dry air (a), dry Ar (b), wet air (c), wet $\operatorname{Ar}(\mathbf{d})$.

The protonic conductivity values were calculated as the difference between values obtained in the wet and dry Ar at the same temperature (Figure 11a). The tendency for conductivity to increase with the increasing unit cell volume is reproduced. However, in the row $\mathrm{BaLaInO}_{4}-\mathrm{Ba}_{1.1} \mathrm{La}_{0.9} \mathrm{InO}_{3.95}-\mathrm{Ba}_{1.1} \mathrm{La}_{0.9} \mathrm{In}_{0.5} \mathrm{Y}_{0.5} \mathrm{O}_{3.95}$ both the size of the interlayer space and the proton concentration (water uptake) increase. Accordingly, calculating the proton mobility for a correct comparison is required:

$$
\mu_{\mathrm{H}}=\sigma_{\mathrm{H}} / \mathrm{Zec}_{\mathrm{H}},
$$

where $\sigma_{\mathrm{H}}$-proton conductivity, Ze-charge $(Z=1), c_{\mathrm{H}}$-volume concentration of protons. As can be seen in Figure 11b, the protonic mobility increases with increasing the size of interlayer space, i.e., with increasing the space for ionic transport.
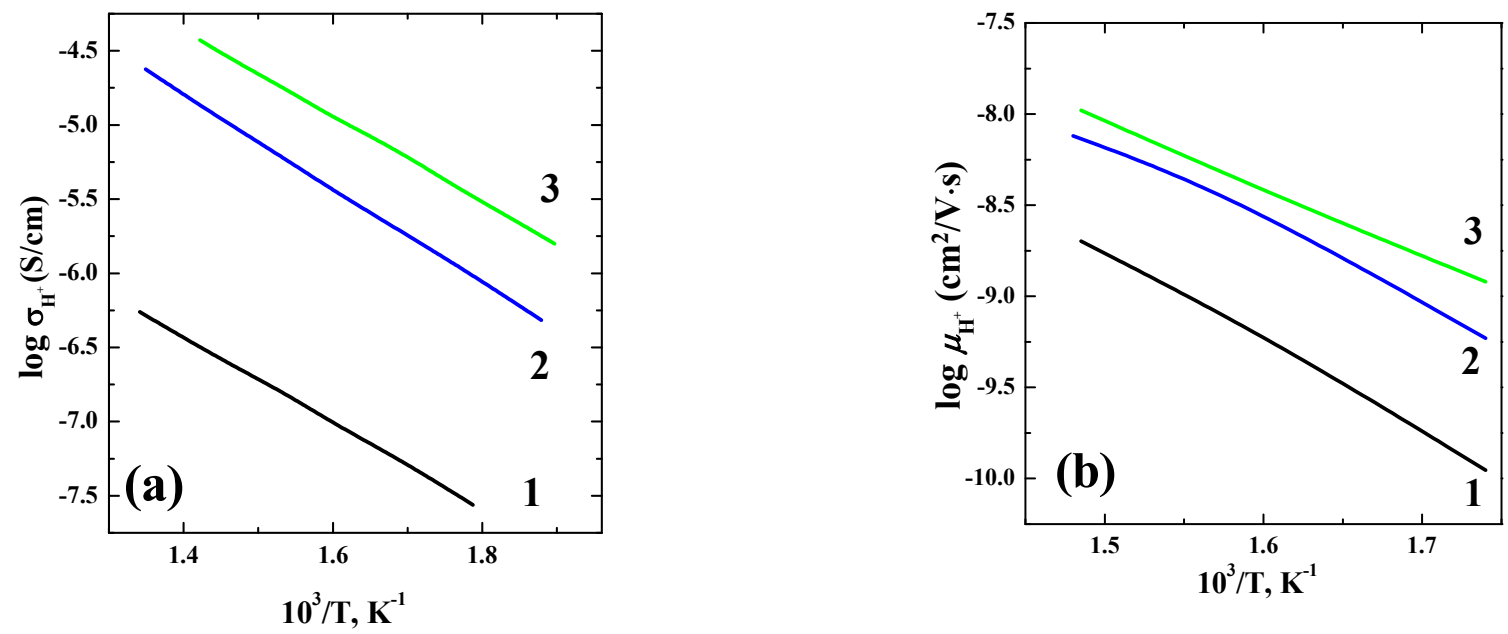

Figure 11. The concentration dependencies of protonic conductivity (a) and protonic mobility (b) for the composition $\mathrm{Ba}_{1.1} \mathrm{La}_{0.9} \mathrm{Y}_{0.5} \mathrm{In}_{0.5} \mathrm{O}_{3.95}$. 
Therefore, the simultaneous doping of barium and indium sublattice by cations with bigger ionic radii leads to the increase of both unit cell volume and water uptake. However, the increasing the proton conductivity values occurs not only by an increase in the proton concentration but by an increase in their mobility as well. This allows us to conclude that the method of simultaneous hetero- and isovalent doping is a very prospective strategy for improving the transport properties of proton conductors with layered perovskite structures.

\section{Conclusions}

In the present work, the method of simultaneous hetero- and isovalent doping for the purpose of improving the transport properties of layered perovskites was investigated. The co-doped complex oxide $\mathrm{Ba}_{1.1} \mathrm{La}_{0.9} \mathrm{In}_{0.5} \mathrm{Y}_{0.5} \mathrm{O}_{3.95}$ was prepared for the first time. It was shown that the co-doping by ions with bigger ionic radii allows for increasing the unit cell volume by up to $4 \%$ and water uptake by three times compared with an undoped $\mathrm{BaLaInO}_{4}$ composition. The correlation of the increase in ionic conductivity with an increase in the unit cell volume and the interlayer space for layered perovskites was confirmed. The increase in the proton conductivity values obtained was both due to the increase in the proton concentration and their mobility. The sample $\mathrm{Ba}_{1.1} \operatorname{La}_{0.9} \operatorname{In}_{0.5} \mathrm{Y}_{0.5} \mathrm{O}_{3.95}$ was nearly a pure proton conductor below $400{ }^{\circ} \mathrm{C}$. The co-doping strategy allows for increasing the protonic conductivity values by up to two orders of magnitude and it is a successful method for the design of novel protonic conductors based on layered perovskites.

Author Contributions: Conceptualization, I.A. and N.T.; methodology, I.A.; investigation, A.G. and K.B.; data curation, N.T. and A.G.; writing-original draft preparation, N.T.; writing-review and editing, N.T. and I.A. All authors have read and agreed to the published version of the manuscript.

Funding: This research was performed according to the budgetary plan of the Institute of High Temperature Electrochemistry and funded by the Budget of Russian Federation.

Institutional Review Board Statement: Not applicable.

Informed Consent Statement: Not applicable.

Data Availability Statement: Not applicable.

Conflicts of Interest: The authors declare no conflict of interest.

\section{References}

1. Iwahara, H.; Esaka, T. Proton conduction in sintered oxides and its application to steam electrolysis for hydrogen production. Solid State Ion. 1981, 3-4, 359-363. [CrossRef]

2. Iwahara, H.; Uchida, H.; Maeda, N. High temperature fuel and steam electrolysis cells using proton conductive solid electrolytes. J. Power Sources 1982, 7, 293-301. [CrossRef]

3. Iwahara, H.; Uchida, H.; Tanaka, S. High temperature type proton conductors based on SrCeO3 and its application to solid electrolyte fuel cells. Solid State Ion. 1983, 9-10, 1021-1026. [CrossRef]

4. Medvedev, D.A. Current drawbacks of proton-conducting ceramic materials: How to overcome them for real electrochemical purposes. Curr. Opin. Green Sustain. Chem. 2021, 32, 100549. [CrossRef]

5. Kim, J.; Sengodan, S.; Kim, S.; Kwon, O.; Bu, Y.; Kim, G. Proton conducting oxides: A review of materials and applic.ations for renewable energy conversion and storage. Renew. Sustain. Energy Rev. 2019, 109, 606-618. [CrossRef]

6. Abdalla, A.M.; Hossain, S.; Nisfindy, O.B.; Azad, A.T.; Dawood, M.; Azad, A.K. Hydrogen production, storage, transportation and key challenges with applications: A review. Energy Convers. Manag. 2018, 165, 602-627. [CrossRef]

7. Hossain, S.; Abdalla, A.M.; Jamain, S.N.B.; Zaini, J.H.; Azad, A.K. A review on proton conducting electrolytes for clean energy and intermediate temperature-solid oxide fuel cells. Renew. Sustain. Energy Rev. 2017, 79, 750-764. [CrossRef]

8. Iwahara, H.; Yajima, T.; Hibino, T.; Ozaki, K.; Suzuki, H. Protonic conduction in calcium, strontium and barium zirconates. Solid State Ion. 1993, 61, 65-69. [CrossRef]

9. Iwahara, H.; Yajima, T.; Ushida, H. Effect of ionic radii of dopants on mixed ionic conduction $\left(\mathrm{H}^{+}+\mathrm{O}^{2-}\right)$ in $\mathrm{BaCeO}_{3}$-based electrolytes. Solid State Ion. 1994, 70-71, 267-271. [CrossRef]

10. Yamazaki, Y.; Hernandez-Sanchez, R.; Haile, S.M. Cation non-stoichiometry in yttrium-doped barium zirconate: Phase behavior, microstructure, and proton conductivity. J. Mater. Chem. 2010, 20, 8158-8166. [CrossRef]

11. Ling, C.D.; Avdeev, M.; Kutteh, R.; Kharton, V.V.; Yaremchenko, A.A.; Fialkova, S.; Sharma, N.; Macquart, R.B.; Hoelzel, M.; Gutmann, M. Phase Transitions, Hydration, and Ionic Conductivity of $\mathrm{Ba}_{4} \mathrm{Nb}_{2} \mathrm{O}_{9}$. Chem. Mater. 2009, 21, 3853-3864. [CrossRef] 
12. Ling, C.D.; Avdeev, M.; Kharton, V.V.; Yaremchenko, A.A.; Macquart, R.B.; Hoelzel, M. Phase Transitions, Hydration, and Ionic Conductivity of $\mathrm{Ba}_{4} \mathrm{Ta}_{2} \mathrm{O}_{9}$. Chem. Mater. 2010, 22, 532-540. [CrossRef]

13. Dunstan, M.T.; Pavan, A.F.; Kharton, V.V.; Avdeev, M.; Kimpton, J.A.; Kolotygin, V.A.; Tsipis, E.V.; Ling, C.D. Phase behavior and mixed ionic-electronic conductivity of $\mathrm{Ba}_{4} \mathrm{Sb}_{2} \mathrm{O}_{9}$. Solid State Ion. 2013, 235, 1-7. [CrossRef]

14. Fop, S.; Skakle, J.M.S.; McLaughlin, A.C.; Connor, P.A.; Irvine, J.T.S.; Smith, R.I.; Wildman, E.J. Oxide Ion Conductivity in the Hexagonal Perovskite Derivative $\mathrm{Ba}_{3} \mathrm{MoNbO}_{8.5}$. J. Am. Chem. Soc. 2016, 138, 16764-16769. [CrossRef] [PubMed]

15. Fop, S.; McCombie, K.S.; Wildman, E.J.; Skakle, J.M.S.; Irvine, J.T.S.; Connor, P.A.; Savaniu, C.; Ritter, C.; McLaughlin, A.C. High oxide ion and proton conductivity in a disordered hexagonal perovskite. Nat. Mater. 2020, 19, 752-757. [CrossRef] [PubMed]

16. Yashima, M.; Tsujiguchi, T.; Sakuda, Y.; Yasui, Y.; Zhou, Y.; Fujii, K.; Torii, S.; Kamiyama, T.; Skinner, S.J. High oxide-ion conductivity through the interstitial oxygen site in $\mathrm{Ba}_{7} \mathrm{Nb}_{4} \mathrm{MoO}_{20}$-based hexagonal perovskite related oxides. Nat. Comm. 2021, 12, 556. [CrossRef] [PubMed]

17. Murakami, T.; Hester, J.R.; Yashima, M. High Proton Conductivity in $\mathrm{Ba}_{5} \mathrm{Er}_{2} \mathrm{Al}_{2} \mathrm{ZrO}_{13}$, a Hexagonal Perovskite-Related Oxide with Intrinsically Oxygen-Deficient Layers. J. Am. Chem. Soc. 2020, 142, 11653-11657. [CrossRef] [PubMed]

18. Animitsa, I.; Denisova, T.; Neiman, A.; Nepryahin, A.; Kochetova, N.; Zhuravlev, N.; Colomban, P. States of $\mathrm{H}^{+}$-containing species and proton migration forms in hydrated niobates and tantalates of alkaline-earth metals with a perovskite-related structure. Solid State Ion. 2003, 162-163, 73-81. [CrossRef]

19. Animitsa, I.; Neiman, A.; Kochetova, N.; Korona, D.; Sharafutdinov, A. Chemical diffusion of water in the double perovskites $\mathrm{Ba}_{4} \mathrm{Ca}_{2} \mathrm{Nb}_{2} \mathrm{O}_{11}$ and $\mathrm{Sr}_{6} \mathrm{Ta}_{2} \mathrm{O}_{11}$. Solid State Ion. 2006, 177, 2363-2368. [CrossRef]

20. Tarasova, N.; Colomban, P.; Animitsa, I. The short-range structure and hydration process of fluorine-substituted double perovskites based on barium-calcium niobate $\mathrm{Ba}_{2} \mathrm{CaNbO}_{5.5}$. J. Phys. Chem. Solids 2018, 118, 32-39. [CrossRef]

21. Troncoso, L.; Arce, M.D.; Fernández-Díaz, M.T.; Mogni, L.V.; Alonso, J.A. Water insertion and combined interstitial-vacancy oxygen conduction in the layered perovskites $\mathrm{La}_{1.2} \mathrm{Sr}_{0.8-\mathrm{x}} \mathrm{Ba}_{x} \mathrm{InO}_{4+\delta}$. New J. Chem. 2019, 43, 6087-6094. [CrossRef]

22. Zhou, Y.; Shiraiwa, M.; Nagao, M.; Fujii, K.; Tanaka, I.; Yashima, M.; Baque, L.; Basbus, J.F.; Mogni, L.V.; Skinner, S.J. Protonic Conduction in the $\mathrm{BaNdInO}_{4}$ Structure Achieved by Acceptor Doping. Chem. Mater. 2021, 33, 2139-2146. [CrossRef] [PubMed]

23. Shiraiwa, M.; Kido, T.; Fujii, K.; Yashima, M. High-temperature proton conductors based on the (110) layered perovskite $\mathrm{BaNdScO}_{4}$. J. Mater. Chem. A 2021, 9, 8607. [CrossRef]

24. Tarasova, N.; Animitsa, I.; Galisheva, A.; Korona, D. Incorporation and Conduction of Protons in Ca, $\mathrm{Sr}, \mathrm{Ba}_{-} \mathrm{Doped} \mathrm{BaLaInO} 4$ with Ruddlesden-Popper Structure. Materials 2019, 12, 1668. [CrossRef] [PubMed]

25. Tarasova, N.; Animitsa, I.; Galisheva, A.; Pryakhina, V. Protonic transport in the new phases BaLaIn $0.9 \mathrm{M}_{0.1} \mathrm{O}_{4.05}(\mathrm{M}=\mathrm{Ti}$, $\mathrm{Zr})$ with Ruddlesden-Popper structure. Solid State Sci. 2020, 101, 106121. [CrossRef]

26. Tarasova, N.; Animitsa, I.; Galisheva, A. Electrical properties of new protonic conductors $\mathrm{Ba}_{1+\mathrm{x}} \mathrm{La}_{1-\mathrm{x}} \mathrm{InO}_{4-0.5 \mathrm{x}}$ with RuddlesdenPopper structure. J. Solid State Electrochem. 2020, 24, 1497-1508. [CrossRef]

27. Tarasova, N.; Galisheva, A.; Animitsa, I. Improvement of oxygen-ionic and protonic conductivity of BaLaInO $\mathrm{B}_{4}$ through Ti doping. Ionics 2020, 26, 5075-5088. [CrossRef]

28. Tarasova, N.; Animitsa, I.; Galisheva, A. Effect of doping on the local structure of new block-layered proton conductors based on $\mathrm{BaLaInO}_{4}$. J. Raman Spec. 2020, 51, 2290-2297. [CrossRef]

29. Tarasova, N.; Galisheva, A.; Animitsa, I. $\mathrm{Ba}^{2+} / \mathrm{Ti}^{4+}$ - co-doped layered perovskite $\mathrm{BaLaInO}_{4}$ : The structure and ionic $\left(\mathrm{O}^{2-}, \mathrm{H}^{+}\right)$ conductivity. Int. J. Hydrog. Energy 2021, 46, 16868-16877. [CrossRef]

30. Tarasova, N.; Animitsa, I.; Galisheva, A. Spectroscopic and transport properties of Ba- and Ti-doped BaLaInO 4 . J. Raman Spec. 2021, 52, 980-987. [CrossRef]

31. Tarasova, N.; Animitsa, I.; Galisheva, A. Effect of acceptor and donor doping on the state of protons in block-layered structures based on $\mathrm{BaLaInO}_{4}$. Solid State Comm. 2021, 323, 14093. [CrossRef]

32. Zhang, G.B.; Smyth, D.M. Protonic conduction in $\mathrm{Ba}_{2} \mathrm{In}_{2} \mathrm{O}_{5}$. Solid State Ion. 1995, 82, 153-160. [CrossRef]

33. Schober, T.; Friedrich, J.; Krug, F. Phase transition in the oxygen and proton conductor $\mathrm{Ba}_{2} \mathrm{In}_{2} \mathrm{O}_{5}$ in humid atmospheres below $300{ }^{\circ}$ C. Solid State Ion. 1997, 99, 9-13. [CrossRef]

34. Schober, T.; Friedrich, J. The oxygen and proton conductor Ba2In2O5: Thermogravimetry of proton uptake. Solid State Ion. 1998, 113-115, 369-375. [CrossRef]

35. Shimura, T.; Komori, M.; Iwahara, H. Ionic conduction in pyrochlore-type oxides containing rare earth elements at high temperature. Solid State Ion. 1996, 86-88, 685-689. [CrossRef]

36. Omata, T.; Okuda, K.; Tsugimoto, S.; Otsuka-Matsuo-Yao, S. Water and hydrogen evolution properties and protonic conducting behaviors of Ca-doped La2Zr2O7 with a pyrochlore structure, Solid State Ion. Solid State Ion. 1997, 104, 249-258. [CrossRef]

37. Sun, W.; Fang, S.; Yan, L.; Liu, W. Investigation on Proton Conductivity of $\mathrm{La}_{2} \mathrm{Ce}_{2} \mathrm{O}_{7}$ in Wet Atmosphere: Dependence on Water Vapor Partial Pressure. Fuel Cells 2012, 12, 457-463. [CrossRef]

38. Besikiotis, V.; Knee, C.S.; Ahmed, I.; Haugsrud, R.; Norby, T. Crystal structure, hydration and ionic conductivity of the inherently oxygen-deficient $\mathrm{La}_{2} \mathrm{Ce}_{2} \mathrm{O}_{7}$. Solid State Ion. 2012, 228, 1-7. [CrossRef]

39. Orera, A.; Slater, P.R. Water incorporation studies in apatite-type rare earth silicates/germinates. Solid State Ion. 2010, 181, 110-114. [CrossRef]

40. Huse, M.; Norby, T.; Haugsrud, R. Proton Conductivity in Acceptor-Doped LaVO. J. Electrochem. Soc. 2011, 158, B857-B865. [CrossRef] 
41. Bjørheim, T.S.; Norby, T.; Haugsrud, R. Hydration and proton conductivity in LaAsO 4 . J. Mater. Chem. 2012, $22,1652-1661$. [CrossRef]

42. Winiarz, P.; Dzierzgowski, K.; Mielewczyk-Gryn, A.; Gazda, M.; Wachowski, S. High-Temperature Proton Conduction in LaSbO 4 . Chem. Eur. J. 2021, 27, 5393-5398. [CrossRef] [PubMed]

43. Li, S.; Schönberger, F.; Slater, P. $\mathrm{La}_{1-\mathrm{x}} \mathrm{Ba}_{1+\mathrm{x}} \mathrm{GaO}_{4-\mathrm{x} / 2}$ : A novel high temperature proton conductor. Chem. Commun. 2003, 21, 2694-2695. [CrossRef] [PubMed]

44. Schönberger, F.; Kendrick, E.; Islam, M.S.; Slater, P.R. Investigation of proton conduction in $\mathrm{La}_{1-\mathrm{x}} \mathrm{Ba}_{1+\mathrm{x}} \mathrm{GaO}_{4-\mathrm{x} / 2}$ and $\mathrm{La}_{1-\mathrm{x}} \mathrm{Sr}_{2+\mathrm{x}} \mathrm{GaO}_{5-\mathrm{x} / 2}$. Solid State Ion. 2005, 176, 2951-2953. [CrossRef]

45. Bjørheim, T.S.; Haugsrud, R.; Norby, T. Protons in acceptor doped langasite, $\mathrm{La}_{3} \mathrm{Ga}_{5} \mathrm{SiO}_{14}$. Solid State Ion. 2014, 264 , 76-84. [CrossRef]

46. Shimura, T.; Fujimoto, S.; Iwahara, H. Proton conduction in non-perovskite-type oxides at elevated temperatures. Solid State Ion. 2001, 134, 117-123. [CrossRef]

47. Partin, G.S.; Korona, D.V.; Neiman, A.Y.; Belova, K.G. Conductivity and Hydration of Fluorite-Type La $\mathrm{La}_{6-\mathrm{x}} \mathrm{WO}_{12-1.5 \mathrm{x}} \mathrm{Phases}(\mathrm{x}=$ $0.4 ; 0.6 ; 0.8 ; 1)$. Russ. J. Electrochem. 2015, 51, 381-390. [CrossRef]

48. Haugsrud, R. Defects and transport properties in $\mathrm{Ln}_{6} \mathrm{WO}_{12}$ (Ln=La, Nd, Gd, Er). Solid State Ion. 2007, 178, 555-560. [CrossRef]

49. Haugsrud, R.; Norby, T. Proton conduction in rare-earth ortho-niobates and ortho-tantalates. Nat. Mater. 2006, 5, 193-196. [CrossRef]

50. Haugsrud, R.; Norby, T. High-temperature proton conductivity in acceptor-doped LaNbO4. Solid State Ion. 2006, 177, 1129-1135. [CrossRef]

51. Haugsrud, R.; Norby, T. High-Temperature Proton Conductivity in Acceptor-Substituted Rare-Earth Ortho-Tantalates LnTaO 4 . J. Am. Ceram. Soc. 2007, 90, 1116-1121. [CrossRef]

52. Shimura, T.; Tokiwa, Y.; Iwahara, H. Protonic conduction in lanthanum strontium aluminate and lanthanum niobate-based oxides at elevated temperatures. Solid State Ion. 2002, 154-155, 653-658. [CrossRef]

53. Haugsrud, R.; Risberg, T. Protons in Acceptor-Doped $\mathrm{La}_{3} \mathrm{NbO}_{7}$ and $\mathrm{La}_{3} \mathrm{TaO}_{7}$. J. Electrochem. Soc. 2009, 156, B425-B428. [CrossRef]

54. Kochetova, N.; Animitsa, I.; Medvedev, D.; Demin, A.; Tsiakaras, P. Recent activity in the development of proton conducting oxides for high-temperature applications. RSC Adv. 2016, 6, 73222. [CrossRef] 